\title{
Study on the enhancement of corn stover fermentation by bioactive water
}

\author{
Jiaoyang $\mathrm{He}^{1 \#}$, Chongming Yang ${ }^{2 \#}$ and Guangchun $\mathrm{Li}^{1,3^{*}}$ \\ ${ }^{1}$ Department of Animal Science, Agricultural college of Yanbian University, Yanji, Jilin, 133002, P.R. China \\ ${ }^{2}$ Department of Environmental Science, college of Geography and Ocean Science, Yanbian University, Hunchun, Jilin, 133300, P.R. \\ China \\ ${ }^{3}$ Engineering Research Center of North-East Cold Region Beef Cattle Science \& Technology Innovation, Ministry of Education, Yanbian \\ University \\ \#Jiaoyang He and Chongming Yang contributed equally to this work
}

\begin{abstract}
In order to explore the role of bioactive water in corn stover fermentation, the moisture content in corn stover fermentation was regulated by DW and bioactive water for this experiment, and the sensory comprehensive assessment, cellulose and hemicellulose degradation rates were analyzed. The results showed that the comprehensive score on the $5 \mathrm{~d}$ was higher than that on the $10 \mathrm{~d}$ from the sensory evaluation analysis, and the sterilized corn stover fermentation was superior to the unsterilized corn stover fermentation, with the total score of treat1 (sterilized stover $+\mathrm{BW}$ ) and treat4 (sterilized stover $+\mathrm{BW}+\mathrm{MYB} 3$ ) higher than the other treatment groups. For sterilized and unsterilized stover, the maximum cellulose and hemicellulose decomposition rates occurred in the four groups (sterilized / unsterilized stover + BW + MYB3) treated in 10 $\mathrm{d}$, which were $39.38 \%, 45.25 \%, 32.25 \%$, and $38.63 \%$, respectively. It nearly doubled compared with the control (sterilized / unsterilized stover + DW). The results show that bioactive water could improve the decomposition rate of stover cellulose and hemicellulose, and it is of great significance to provide a new feasible method for the application of stover fermentation.
\end{abstract}

\section{Introduction}

China is very rich in stover resources, with an annual stover production of about 900 million tons, but the number of stover used as feed does not exceed $20 \%$. As a bioenergy that can be used for development and utilization, the greatest advantages of stover are that it is very rich in resources, has a common source, and has a great potential for research and development. Although the number is huge, the utilization rate has been very low since ancient times, not only the investment cost is high in the utilization process, the technology used is also relatively backward, but also the industrialization degree is very low, which causes the waste of a large number of stover resources and environmental pollution ${ }^{[1]}$. If stover can be reasonably utilized, such as making feed, it can effectively improve its application value, and at the same time solve a series of problems such as natural environment changes and natural pasture yield decline faced in animal husbandry development ${ }^{[2]}$.

The full use of stover resources plays an important role in China's agricultural economy. The number of stover in China is increasing year by year. Compared with direct incineration, if the stover resources are fully utilized, they not only protect the ecological environment and contribute to the cause of environmental protection, but also obtain rich and cheap resources. Second, the fertilizing of stover can reduce the use of a large number of chemical fertilizers and improve the quality of soil. Long-term application of chemical fertilizers can cause serious damage to soil structure, while application of organic fertilizers can reduce these problems, and gradually improve the soil's water and fertilizer retention capacity and promote sustainable development ${ }^{[3]}$. It can also promote the agricultural circular economy, feed stover into feed to livestock, which will greatly reduce part of the grain output and solve the problem of human and animal grain competition. This alleviates the food shortage problem, to some extent, and the stover resources are reused, which promotes the sustainable development of agricultural economy.

The rational use of stover resources is the general trend. So many developing countries currently choose to ferment stover into yellow storage for livestock feed ${ }^{[4]}$. However, stover feed cannot be fully utilized because of its high cellulose content, poor palatability, and low digestibility of feed. In the feed utilization of corn stover, in order to improve its palatability, facilitate the feeding and digestion of livestock and poultry, and prolong the storage time, it is necessary to further reduce the contents of cellulose and hemicellulose in the stover.

According to the survey, bioactive water can be applied in the cropping industry, mainly to improve crop quality and yield, soil improvement and inhibition of pests and diseases. At the same time, it is also widely used in composting and decomposing, improving the microbial

\footnotetext{
${ }^{*}$ Corresponding author: gcli@ybu.edu.cn
} 
environment of livestock and poultry sheds, etc., which can form organic circulating agriculture. Through the combination of microorganisms, minerals and water in nature, livestock and poultry manure becomes "waste" to "treasure", creating an artificial circulatory system similar to natural purification procedures, and so that sewage maintains activity while purifying, can be reused without secondary pollution. The application range is very wide. It was reported that this technology had been used by Japanese farm enterprises or farmers for nearly 30 years ${ }^{[5-}$ 6].

In this study, bioactive water was used to treat corn stover fermentation to improve the quality of corn stover fermentation, which has a high reference value for the application of bioactive water.

\section{Materials and Methods}

\subsection{Materials and medium}

Corn dry stover harvested at maturity (provided by the pasture of the College of Agriculture) was taken and crushed $2 \sim 3 \mathrm{~cm}$ in length. Cellulose content was measured as $29.83 \%$ and hemicellulose content as $28.86 \%$ in the corn stover used for the experiment. Fermentation preparation: Cellulolytic bacteria MYB3 was provided by the laboratory. Strain MYB3 cultivation was prepared with LB medium, and adjusted to $\mathrm{OD}_{600 \mathrm{~nm}} 1.0$, at $4{ }^{\circ} \mathrm{C}$ for seeding. Experimentally used bioactive water (BW) was prepared by aeration of Pellet and pumice in water at a certain ratio ${ }^{[7]}$.

Mineral Salt Medium(MSM): $\mathrm{NaCl} 0.01 \mathrm{~g}, \mathrm{KH}_{2} \mathrm{PO}$ $40.5 \mathrm{~g}, \mathrm{~K}_{2} \mathrm{HPO} 40.5 \mathrm{~g}, \mathrm{MgCl}_{2} \bullet 6 \mathrm{H}_{2} \mathrm{O} 0.2 \mathrm{~g}, \mathrm{MnSO}_{4} 0.339$ $\mathrm{mg}, \mathrm{ZnSO}_{4} 0.428 \mathrm{mg}, \mathrm{CaCl}_{2} \bullet 6 \mathrm{H}_{2} \mathrm{O} 0.026 \mathrm{~g}, \mathrm{H}_{8} \mathrm{MoN}_{2} \mathrm{O}_{4}$ $0.347 \mathrm{mg}$, Yeast extract $0.2 \mathrm{~g}$, DW $1 \mathrm{~L}$. LB: peptone $10 \mathrm{~g}$, yeast extract $5 \mathrm{~g}, \mathrm{NaCl} 10 \mathrm{~g}, \mathrm{DW} 1 \mathrm{~L}$.

\subsection{Experimental Design}

Weighed $50 \mathrm{~g}$ of air-dried stover in a sealed bag, calculate the water content that should be added in each group in advance when loading the bag, adjusted the water content using the deionized water (DW), mineral salt medium (MSM) and bioactive water (BW) of the laboratory, perform 3 replicates for each treatment, and at the same time, took the dried stover sterilized in the autoclave to do the same treatment as above. The water content in each fermentation bag was controlled to be $60 \%$, and the inoculum size of MYB3 was 5\% (v/v), which was placed in an incubator at $30{ }^{\circ} \mathrm{C}$. The cellulose, hemicellulose content and $\mathrm{pH}$ were analysis on $5 \mathrm{~d}$ and $10 \mathrm{~d}$, respectively, and sensory evaluation was performed (table 1).

\subsection{Analysis methods}

The fermentation in the sealed bag was assessed sensory evaluation according to the silage evaluation criteria, including $\mathrm{pH}$, moisture content, color, odor, and texture, respectively ${ }^{[8]}$.

To determine the $\mathrm{pH}$, weighed $5.00 \mathrm{~g}$ of stover fermentation into an Erlenmeyer flask, added $45 \mathrm{ml} \mathrm{DW}$, seal, placed at $4^{\circ} \mathrm{C}$. Extracted $2 \mathrm{ml}$ of extract from the Erlenmeyer flask 24 hours later, and test used a pH meter.

Cellulose, hemicellulose to pretreated with a mixture of acetic acid and nitric acid, and analysised by DNS methods ${ }^{[9-10]}$

Table 1. Experimental grouping

\begin{tabular}{cl}
\hline Treatment & \multicolumn{1}{c}{ Combination mode } \\
\hline Control & Sterilized/Unsterilized corn stover+DW \\
Treat1 & Sterilized/Unsterilized corn stover+BW \\
Treat2 & Sterilized/Unsterilized corn stover+MSM \\
Treat3 & Sterilized/Unsterilized corn stover+DW+MYB3 \\
Treat4 & Sterilized/Unsterilized corn stover+BW+MYB3 \\
Treat5 & Sterilized/Unsterilized corn stover+MSM+MYB3 \\
\hline
\end{tabular}

\section{Results and Discussion}

\subsection{Comprehensive score of stover fermentation}

As can be seen from Table 2 and Table 3, the $\mathrm{pH}$ value of the silage stover on the $10 \mathrm{~d}$ of fermentation was slightly lower than that on the $5 \mathrm{~d}$, while the $\mathrm{pH}$ value of each experimental group after sterilization treatment was less than that of each experimental group without sterilization. Among them, the $\mathrm{pH}$ of each experimental group treated with bioactive water was less than that of the other experimental groups, and reduce the $\mathrm{pH}$ of silage was improved the silage effect. And the evaluation score of the sterilized group was also slightly higher than that of the unsterilized group, indicating that the fermentation effect of the sterilized group was better than that of the unsterilized group. As a whole, the fermentation quality of stover treated with sterilization was better than that of stover treated without sterilization.

The initial water content of the two groups was $60 \%$, and the fermentation temperature was $30^{\circ} \mathrm{C}$. From the perspective of $\mathrm{pH}$ and the results of overall sensory evaluation (Table 2, Table 3 ). The overall score of each treatment group on the $5 \mathrm{~d}$ of fermentation in both groups was higher than that on the $10 \mathrm{~d}$, and the fermentation effect on the $5 \mathrm{~d}$ was better than that on the $10 \mathrm{~d}$. Among them, the scores of the two experimental groups treat 1 $($ stover + BW) and treat4 (stover + BW + MYB3) were treatment group using bioactive water fermentation was better than that of other treatment groups.

Table 2. Comprehensive score of corn stover silage on the $5 \mathrm{~d}$

\begin{tabular}{|c|c|c|c|c|c|c|}
\hline Treatment & pH & $\begin{array}{c}\text { Moisture } \\
(\%)\end{array}$ & Colour & Smell & Texture & Result \\
\hline \multicolumn{7}{|c|}{ Unsterilized } \\
\hline $\begin{array}{l}\text { Control } \\
\text { (Score) }\end{array}$ & $\begin{array}{l}6.37 \\
(0)\end{array}$ & $\begin{array}{c}52 \\
(20)\end{array}$ & $\begin{array}{c}\text { Yellow } \\
(15)\end{array}$ & $\begin{array}{l}\text { Light } \\
\text { sour } \\
(15)\end{array}$ & $\begin{array}{c}\text { Soft } \\
\text { moisture } \\
\text { (7) }\end{array}$ & $\begin{array}{l}\text { Good } \\
(57)\end{array}$ \\
\hline Trea1 & 6.39 & 50 & $\begin{array}{l}\text { Bright } \\
\text { yellow }\end{array}$ & $\begin{array}{l}\text { Light } \\
\text { sour }\end{array}$ & $\begin{array}{c}\text { Soft and } \\
\text { dry }\end{array}$ & Good \\
\hline (Score) & $(0)$ & (20) & (18) & (17) & (9) & (64) \\
\hline Trea2 & 6.40 & 52 & Yellow & $\begin{array}{c}\text { Light } \\
\text { sour }\end{array}$ & $\begin{array}{c}\text { Soft } \\
\text { moisture }\end{array}$ & Good \\
\hline
\end{tabular}




\begin{tabular}{|c|c|c|c|c|c|c|}
\hline (Score) & (0) & (20) & (13) & (15) & (7) & (55) \\
\hline $\begin{array}{l}\text { Treat3 } \\
\text { (Score) }\end{array}$ & $\begin{array}{c}6.26 \\
(0)\end{array}$ & $\begin{array}{c}50 \\
(20)\end{array}$ & $\begin{array}{l}\text { Faint } \\
\text { yellow } \\
(13)\end{array}$ & $\begin{array}{c}\text { Light } \\
\text { sour } \\
\text { (13) }\end{array}$ & $\begin{array}{c}\text { Soft } \\
\text { moisture } \\
(8)\end{array}$ & $\begin{array}{l}\text { Good } \\
(54)\end{array}$ \\
\hline $\begin{array}{c}\text { Trea4 } \\
\text { (Score) }\end{array}$ & $\begin{array}{l}6.35 \\
(0)\end{array}$ & $\begin{array}{c}49 \\
(20)\end{array}$ & $\begin{array}{c}\text { Bright } \\
\text { yellow } \\
(17)\end{array}$ & $\begin{array}{c}\text { Light } \\
\text { sour } \\
(15)\end{array}$ & $\begin{array}{c}\text { Soft and } \\
\text { dry } \\
(9)\end{array}$ & $\begin{array}{l}\text { Good } \\
\text { (61) }\end{array}$ \\
\hline $\begin{array}{l}\text { Treat5 } \\
\text { (Score) }\end{array}$ & $\begin{array}{l}6.38 \\
(0)\end{array}$ & $\begin{array}{c}51 \\
(20)\end{array}$ & $\begin{array}{c}\text { Faint } \\
\text { yellow } \\
(14) \\
\text { Sterilized }\end{array}$ & $\begin{array}{l}\text { Light } \\
\text { sour } \\
(15) \\
\text { d }\end{array}$ & $\begin{array}{c}\text { Soft } \\
\text { moisture } \\
(8)\end{array}$ & $\begin{array}{l}\text { Good } \\
(57)\end{array}$ \\
\hline $\begin{array}{l}\text { Control } \\
\text { (Score) }\end{array}$ & $\begin{array}{l}5.46 \\
(0)\end{array}$ & $\begin{array}{c}51 \\
(20)\end{array}$ & $\begin{array}{c}\text { Yellow } \\
\text { brown } \\
(12)\end{array}$ & $\begin{array}{c}\text { Sweet } \\
\text { and sour } \\
(18)\end{array}$ & $\begin{array}{c}\text { Wet and } \\
\text { soft } \\
(6)\end{array}$ & $\begin{array}{l}\text { Good } \\
(56)\end{array}$ \\
\hline $\begin{array}{l}\text { Treat1 } \\
\text { (Score) }\end{array}$ & $\begin{array}{l}5.29 \\
(0)\end{array}$ & $\begin{array}{c}49 \\
(20)\end{array}$ & $\begin{array}{c}\text { Yellow } \\
(14)\end{array}$ & $\begin{array}{l}\text { Sweet } \\
\text { and sour } \\
(22)\end{array}$ & $\begin{array}{c}\text { Soft } \\
\text { moisture } \\
(8)\end{array}$ & $\begin{array}{l}\text { Good } \\
(64)\end{array}$ \\
\hline $\begin{array}{l}\text { Treat2 } \\
\text { (Score) }\end{array}$ & $\begin{array}{l}5.34 \\
(0)\end{array}$ & $\begin{array}{c}50 \\
(20)\end{array}$ & $\begin{array}{c}\text { Yellow } \\
\text { brown } \\
(13)\end{array}$ & $\begin{array}{l}\text { Sweet } \\
\text { and sour } \\
(19)\end{array}$ & $\begin{array}{c}\text { Wet and } \\
\text { soft } \\
(7)\end{array}$ & $\begin{array}{l}\text { Good } \\
(59)\end{array}$ \\
\hline $\begin{array}{l}\text { Treat3 } \\
\text { (Score) }\end{array}$ & $\begin{array}{l}5.79 \\
(0)\end{array}$ & $\begin{array}{c}49 \\
(20)\end{array}$ & $\begin{array}{c}\text { Brown } \\
\text { yellow } \\
(10)\end{array}$ & $\begin{array}{l}\text { Light } \\
\text { sour } \\
(17)\end{array}$ & $\begin{array}{c}\text { Soft } \\
\text { moisture } \\
(8)\end{array}$ & $\begin{array}{l}\text { Good } \\
(55)\end{array}$ \\
\hline $\begin{array}{l}\text { Treat4 } \\
\text { (Score) }\end{array}$ & $\begin{array}{l}5.66 \\
(0)\end{array}$ & $\begin{array}{c}48 \\
(20)\end{array}$ & $\begin{array}{c}\text { Yellow } \\
\text { brown } \\
(12)\end{array}$ & $\begin{array}{l}\text { Sweet } \\
\text { and sour } \\
(22)\end{array}$ & $\begin{array}{c}\text { Soft and } \\
\text { dry } \\
(9)\end{array}$ & $\begin{array}{l}\text { Good } \\
\text { (63) }\end{array}$ \\
\hline $\begin{array}{l}\text { Treat5 } \\
\text { (Score) }\end{array}$ & $\begin{array}{l}5.59 \\
(0) \\
\end{array}$ & $\begin{array}{r}49 \\
(20) \\
\end{array}$ & $\begin{array}{c}\text { Brown } \\
\text { yellow } \\
(11)\end{array}$ & $\begin{array}{l}\text { Light } \\
\text { sour } \\
(18)\end{array}$ & $\begin{array}{c}\text { Wet and } \\
\text { soft } \\
(8)\end{array}$ & $\begin{array}{l}\text { Good } \\
(57)\end{array}$ \\
\hline
\end{tabular}

Note:
1. The total score is 100 points, including $\mathrm{pH}: 25$ points, water content: 20 points, color: 20 points, odor: 25 points, texture: 10 points.

2. the values in parentheses indicate the score.

3. Grade division: excellent score $100 \sim 75$ points, good score $75 \sim 51$ points, general score $50 \sim 26$ points, inferior score less than 25 points.

Table 3. Comprehensive score of corn stover silage on $10 \mathrm{~d}$

\begin{tabular}{|c|c|c|c|c|c|c|}
\hline Treatment & pH & $\begin{array}{c}\text { Moisture } \\
(\%)\end{array}$ & Colour & Smell & Texture & Result \\
\hline \multicolumn{7}{|c|}{ Unsterilized } \\
\hline $\begin{array}{l}\text { Control } \\
\text { (Score) }\end{array}$ & $\begin{array}{c}6.33 \\
(0)\end{array}$ & $\begin{array}{l}43 \\
(20)\end{array}$ & $\begin{array}{c}\text { Brown } \\
\text { (7) }\end{array}$ & $\begin{array}{l}\text { Sour } \\
\text { (10) }\end{array}$ & $\begin{array}{l}\text { Slightly } \\
\text { sticky } \\
\text { (4) }\end{array}$ & $\begin{array}{c}\text { Common } \\
\text { (41) }\end{array}$ \\
\hline $\begin{array}{l}\text { Treat1 } \\
\text { (Score) }\end{array}$ & $\begin{array}{l}6.15 \\
(0)\end{array}$ & $\begin{array}{l}40 \\
(20)\end{array}$ & $\begin{array}{c}\text { Yellow } \\
\text { brown } \\
(12)\end{array}$ & $\begin{array}{l}\text { Sour } \\
\text { (12) }\end{array}$ & $\begin{array}{c}\text { Soft } \\
\text { moisture } \\
(7)\end{array}$ & $\begin{array}{l}\text { Good } \\
(51)\end{array}$ \\
\hline $\begin{array}{l}\text { Treat2 } \\
\text { (Score) }\end{array}$ & $\begin{array}{c}6.16 \\
(0)\end{array}$ & $\begin{array}{l}42 \\
(20)\end{array}$ & $\begin{array}{c}\text { Brown } \\
(8)\end{array}$ & $\begin{array}{l}\text { Sour } \\
(10)\end{array}$ & $\begin{array}{c}\text { Wet and } \\
\text { soft } \\
(6)\end{array}$ & $\begin{array}{c}\text { Common } \\
\text { (44) }\end{array}$ \\
\hline $\begin{array}{l}\text { Treat3 } \\
\text { (Score) }\end{array}$ & $\begin{array}{c}6.00 \\
(0)\end{array}$ & $\begin{array}{l}41 \\
(20)\end{array}$ & $\begin{array}{c}\text { Brown } \\
\text { (7) }\end{array}$ & $\begin{array}{l}\text { Sour } \\
\text { (10) }\end{array}$ & $\begin{array}{l}\text { Slightly } \\
\text { sticky } \\
\text { (4) }\end{array}$ & $\begin{array}{c}\text { Common } \\
\text { (41) }\end{array}$ \\
\hline $\begin{array}{l}\text { Treat4 } \\
\text { (Score) }\end{array}$ & $\begin{array}{l}5.91 \\
(0)\end{array}$ & $\begin{array}{l}40 \\
(20)\end{array}$ & $\begin{array}{c}\text { Brown } \\
\text { yellow } \\
(10)\end{array}$ & $\begin{array}{l}\text { Light } \\
\text { sour } \\
(15)\end{array}$ & $\begin{array}{c}\text { Wet and } \\
\text { soft } \\
(7)\end{array}$ & $\begin{array}{l}\text { Good } \\
(52)\end{array}$ \\
\hline $\begin{array}{l}\text { Treat5 } \\
\text { (Score) }\end{array}$ & $\begin{array}{l}5.79 \\
(0)\end{array}$ & $\begin{array}{l}40 \\
(20)\end{array}$ & $\begin{array}{c}\text { Brown } \\
\text { (7) }\end{array}$ & $\begin{array}{c}\text { Light } \\
\text { sour } \\
(11)\end{array}$ & $\begin{array}{c}\text { Wet and } \\
\text { soft } \\
(6)\end{array}$ & $\begin{array}{c}\text { Common } \\
\text { (44) }\end{array}$ \\
\hline \multicolumn{7}{|c|}{ Sterilized } \\
\hline $\begin{array}{l}\text { Control } \\
\text { (Score) }\end{array}$ & $\begin{array}{c}4.96 \\
(0)\end{array}$ & $\begin{array}{l}40 \\
(20)\end{array}$ & $\begin{array}{c}\text { Dark } \\
\text { brown } \\
(6)\end{array}$ & $\begin{array}{l}\text { Light } \\
\text { sour } \\
(16)\end{array}$ & $\begin{array}{l}\text { Slightly } \\
\text { sticky } \\
\text { (4) }\end{array}$ & $\begin{array}{c}\text { Common } \\
(46)\end{array}$ \\
\hline $\begin{array}{l}\text { Treat1 } \\
\text { (Score) }\end{array}$ & $\begin{array}{l}4.90 \\
(0)\end{array}$ & $\begin{array}{l}40 \\
(20)\end{array}$ & $\begin{array}{c}\text { Brown } \\
(8)\end{array}$ & $\begin{array}{c}\text { Sweet } \\
\text { and sour } \\
(20)\end{array}$ & $\begin{array}{c}\text { Wet and } \\
\text { soft } \\
(6)\end{array}$ & $\begin{array}{l}\text { Good } \\
(54)\end{array}$ \\
\hline Treat2 & 4.78 & 39 & $\begin{array}{c}\text { Dark } \\
\text { brown }\end{array}$ & $\begin{array}{c}\text { Light } \\
\text { sour }\end{array}$ & $\begin{array}{c}\text { Wet and } \\
\text { soft }\end{array}$ & Common \\
\hline
\end{tabular}

\begin{tabular}{|c|c|c|c|c|c|c|}
\hline (Score) & (1) & (20) & (6) & (15) & (6) & (48) \\
\hline Treat3 & 4.72 & 39 & $\begin{array}{l}\text { Dark } \\
\text { brown }\end{array}$ & $\begin{array}{l}\text { Light } \\
\text { sour }\end{array}$ & $\begin{array}{l}\text { Slightly } \\
\text { sticky }\end{array}$ & Common \\
\hline (Score) & (1) & (20) & (5) & (15) & (5) & (43) \\
\hline Treat4 & 4.62 & 38 & Brown & $\begin{array}{l}\text { Sweet } \\
\text { and sour }\end{array}$ & $\begin{array}{c}\text { Wet and } \\
\text { soft }\end{array}$ & Good \\
\hline (Score) & (3) & (20) & (9) & (21) & (7) & (60) \\
\hline & 4.70 & 39 & $\mathrm{Br}$ & $\begin{array}{l}\text { Light } \\
\text { sour }\end{array}$ & $\begin{array}{l}\text { Slightly } \\
\text { sticky }\end{array}$ & Common \\
\hline (Score) & (1) & (20) & (7) & (16) & (5) & (49) \\
\hline
\end{tabular}

\subsection{Cellulose degradation}

Cellulose content was measured in each experimental group on $5 \mathrm{~d}$ and $10 \mathrm{~d}$ of fermentation, and the analysis results were shown in Fig. 1 and Fig. 2.

According to Fig. 1 and Fig. 2, it can be seen that the cellulose degradation rates of each experiment treated with sterilization were higher than those of each experiment without sterilization, and among them, the degradation rates of the treat4 (stover + BW + MYB3) experimental group treated with sterilization reached $32.94 \%$ and $45.25 \%$ on the $5 \mathrm{~d}$ and $10 \mathrm{~d}$, respectively, which were nearly twice higher than those of the control. These results indicated that the decomposition rate of cellulose in stover can be significantly improved by fermentation of stover with bioactive water.

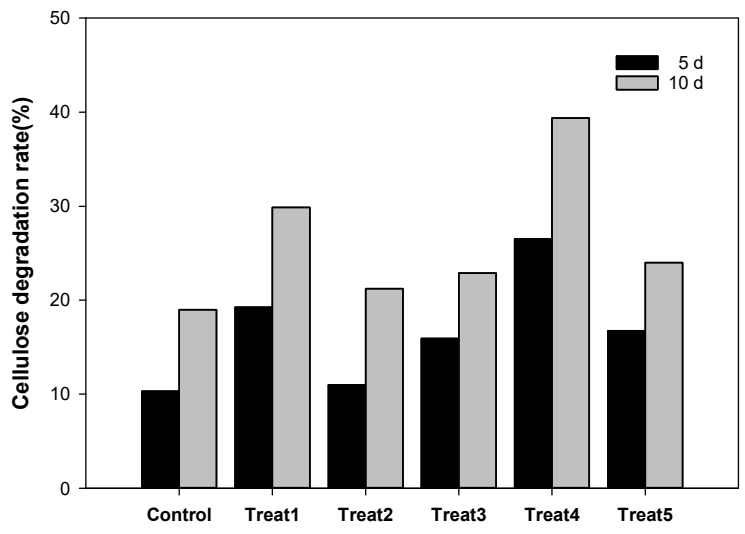

Fig.1. Cellulose degradation rate (unsterilized)

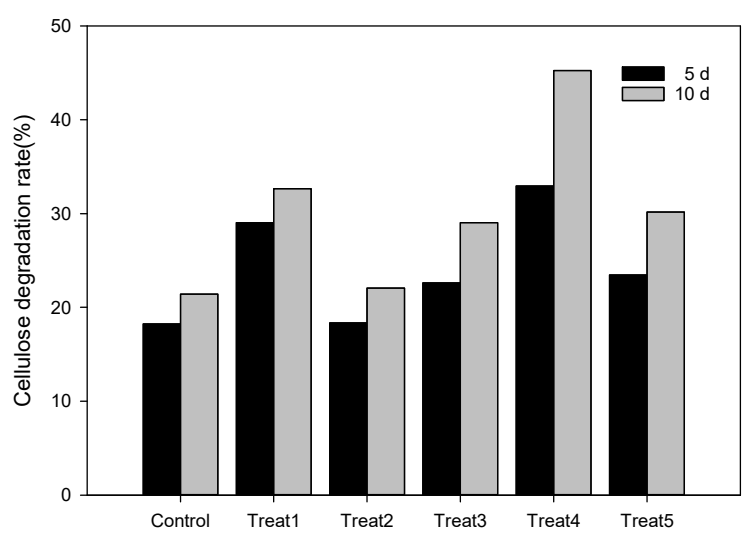

Fig.2. Cellulose degradation rate (sterilized) 


\subsection{Hemicellulose degradation}

The hemicellulose content of each experimental group was measured on the $5 \mathrm{~d}$ and $10 \mathrm{~d}$, and the analysis results were shown in Fig. 3 and Fig. 4.

According to Fig. 3 and Fig. 4, it can be seen that the hemicellulose degradation rate of each experiment with sterilized was higher than that of each experiment without sterilization, and the treat4 (stover + BW + MYB3) experimental group had the highest hemicellulose degradation rate in both the sterilized and the unsterilized experimental group. Among them, the hemicellulose degradation rate of the treat 4 (stover $+\mathrm{BW}+\mathrm{MYB} 3$ ) experimental group reached $29.75 \%$ and $38.63 \%$ on the 5 $\mathrm{d}$ and $10 \mathrm{~d}$, respectively, which was much higher than that of the control. It showed that bioactive water could effectively improve the hemicellulose degradation rate in the stover and achieve good experimental results.

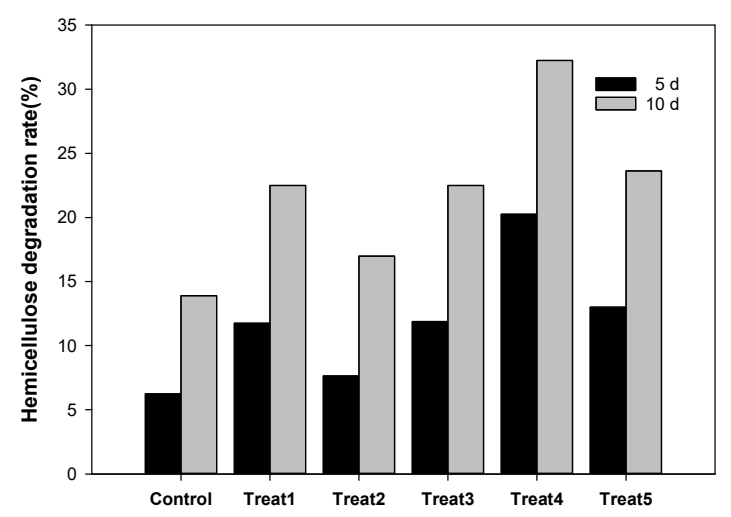

Fig.3. Hemicellulose degradation rate (unsterilized)

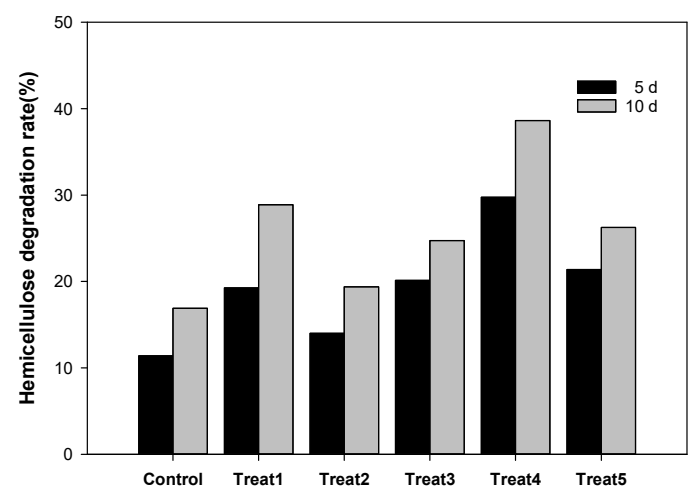

Fig.4. Hemicellulose degradation rate (sterilized)

\section{Conclusion}

The experimental results showed that the comprehensive score of silage on $5 \mathrm{~d}$ was higher than that on $10 \mathrm{~d}$, but the gap was not significant. Among them, the combined scores, cellulose and hemicellulose analysis of treat1 (stover $+\mathrm{BW}$ ) and treat4 (stover $+\mathrm{BW}+\mathrm{MYB} 3)$ were higher than those of the other treatment groups, and BW had a better promoting effect on fermentation of the corn stover.

\section{Acknowledgements}

The study was supported by Open Foundation of Key Laboratory of Industrial Ecology and Environmental Engineering, MOE(KLIEEE-18-05); Engineering Research Center of North-East Cold Region Beef Cattle Science \& Technology Innovation, Ministry of Education, China; 111 Project(D20034)

\section{References}

1. J. X. Si, Hazard of stover combustion and its solution, Ability and Wisdom, 17, 276-277 (2009)

2. X. Y. Liu, H. R. Tian, Effects of yellow storage on corn stover quality and microbial diversity, Journal of Anhui Agricultural Science, 47 (19), 197-200 (2019)

3. A. L. Ammerbeck, S. J. Stetson, S. L. Osborne, et al, Corn residue removalimpact on soil aggregates in a no-till corn/soybean rotation, Soil Science Society of America Journal, 76(4), 1390-1398 (2012)

4. X. Zeng, Y. Ma, L. Ma, Utilization of stover in biomass energy in China, Renew Sots Emerge Rev, (11), 976-987 (2007)

5. X. M. YANG, M. YANG, H. HE, Present situation and technology of waste treatment and recycling in livestock and poultry industry in Japan,Techniques and Equipment for Environmental Pollution Control, 6(3), 5-11 (2005)

6. S. Y. Sheen, C. M. Hong, Disposal of animal waste the magnitude of the problem in Asia and Australasia review,Asian-Australasian Journal of Animal Sciences, 12(4), 597-603 (1999)

7. X. X. Cheng, Study of the influence of bioactive water on the treatment of high concentration organic wastewater, Yanji: Yanbian University (2018)

8. Quality evaluation criteria for silage (trial), China Feed, (21), 5-7 (1996)

9. M. Zhang, X. Z. Xue, Improvement of hemicellulose determination method, Xinjiang Agricultural Sciences, (4), 180 (1994)

10. S. M. Xiong, X. Y. Zuo, Y. Y. Zhu, Determination of cellulose hemicellulose and lignin in rice husk, Gereal and Feed Industry, (8), 40-41 (2005) 